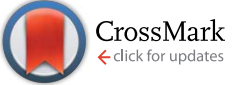

Cite this: RSC Adv., 2017, 7, 14709

\title{
Structure and crystallization behavior of Al containing glasses in the $\mathrm{CaO}-\mathrm{B}_{2} \mathrm{O}_{3}-\mathrm{SiO}_{2}$ system
}

\author{
Jiao Han, ${ }^{\text {*a }}$ Yuanming Lai, ${ }^{\text {b }}$ Yao Xiang, ${ }^{\text {a }}$ Shuang Wu, ${ }^{a}$ Yiming Zeng, ${ }^{\text {*a }}$ Hongwei Yang, ${ }^{a}$ \\ Yongyun $\mathrm{MaO}^{\mathrm{a}}$ and Yuwen Yang ${ }^{\mathrm{a}}$
}

The aim of the present work is to investigate the effects of $\mathrm{Al}_{2} \mathrm{O}_{3}$ content on both the structure and crystallization behavior of $\mathrm{CaO}-\mathrm{B}_{2} \mathrm{O}_{3}-\mathrm{SiO}_{2}$ (CBS) glass composition using NMR, FT-IR and DSC. The density experimental results showed that the density $(\rho)$ of glasses decreased linearly with increasing $\mathrm{Al}_{2} \mathrm{O}_{3}$ content, while the molar volume $\left(V_{\mathrm{m}}\right)$ of the glasses increased linearly. The NMR revealed that the $\mathrm{Al}$ occurred in the forms of $\mathrm{Al}^{\mathrm{IV}}, \mathrm{Al}^{\mathrm{V}}$ and $\mathrm{Al}^{\mathrm{VI}}$ units. With the increasing $\mathrm{Al}_{2} \mathrm{O}_{3}$ content, the amount of $\mathrm{Al}$ species show little change, the relative amount of $B^{\text {Illa }}$ and $B^{\text {Ills }}$ units increases while the $B^{I V}$ units decrease, and the $Q^{4}$ structural units increases clearly but the $Q^{3}$ decreases. Further, crystallization peaks of CBS glasses shift to higher temperatures, indicating that $\mathrm{Al}_{2} \mathrm{O}_{3}$ addition can suppress crystallization of CBS glasses.

Received 4th February 2017

Accepted 27th February 2017

DOI: 10.1039/c7ra01427a

rsc.li/rsc-advances

$\mathrm{ZnO}$ in borate glass structure due to the non-bridging oxygen atoms. The $\mathrm{ZnO}$ played as a network former when having more than 5\% (weight\%) ZnO in glasses, on the contrary, the role was modifier. Khan et al. ${ }^{7}$ did some research about the modification in yttrium calcium borosilicate glasses units by $\mathrm{ZrO}_{2}$ instead of $\mathrm{CaO}$. Interestingly higher content of $\mathrm{ZrO}_{2} \geq 7.5 \mathrm{~mol} \%$ may be acts as glass former and below $7.5 \mathrm{~mol} \%$, it may act as glass modifier. Also, the variation in structure leads to the change of optical and dielectric properties. Neuville et al. ${ }^{9}$ found that $\mathrm{Al} / \mathrm{Si}$ tetrahedral distribution in the glass network in different $\mathrm{Q}^{n}$ units depending on the join $\mathrm{R}=\mathrm{CaO} / \mathrm{Al}_{2} \mathrm{O}_{3}$. The results revealed the remarkable function of aluminum in $\mathrm{CaO}-\mathrm{Al}_{2} \mathrm{O}_{3}-\mathrm{SiO}_{2}$ (CAS) ternary glass system. Aluminoborosilicate glasses consist of structural units, such as $\mathrm{BO}_{3}, \mathrm{BO}_{4},{ }^{10} \mathrm{SiO}_{4},{ }^{11} \mathrm{AlO}_{4}$ and $\mathrm{AlO}_{6}$ (ref. 12) species. The transformation of network formers in aluminosilicate glasses can make the structure of $\mathrm{CaO}-\mathrm{B}_{2} \mathrm{O}_{3}-\mathrm{SiO}_{2}$ glass meet the application need.

However, so far, there is no report about utilizing FT-IR spectra, NMR, DSC and XRD to research the structure and crystallization of calcium aluminoborosilicate glasses with varying $\mathrm{Al}$ content. Therefore, in this paper, we present a detailed report on the structure and crystallization of $\mathrm{CaO}-$ $\mathrm{B}_{2} \mathrm{O}_{3}-\mathrm{SiO}_{2}$ glass with $\mathrm{Al}_{2} \mathrm{O}_{3}$ content, especially the relationship between the $\mathrm{Al}$ content and the impacts on the units of glass network, which will provide guiding significance for further optimization of the glass structure.

\section{Experimental}

${ }^{a}$ State Key Laboratory of Advanced Technologies for Comprehensive Utilization of Platinum Metals, Kunming Institute of Precious Metals, Kunming 650106, PR China. E-mail: hanjiao90@sina.com; zengym0871@126.com

${ }^{b}$ State Key Laboratory of Electronic Thin Films and Integrated Devices, University of Electronic Science and Technology of China, Chengdu 610054, PR China

\subsection{Preparation of glass samples}

The $(1-x / 100) \times\left(35 \mathrm{CaO}-37 \mathrm{SiO}_{2}-28 \mathrm{~B}_{2} \mathrm{O}_{3}\right)+x \mathrm{Al}_{2} \mathrm{O}_{3}$, where $x=$ $0,1,2.5,5,7.5$ and $10 \mathrm{~mol} \%$, were prepared using analytically 
pure $\mathrm{CaCO}_{3}, \mathrm{H}_{3} \mathrm{BO}_{3}, \mathrm{SiO}_{2}$, and $\mathrm{Al}_{2} \mathrm{O}_{3}$ as the starting materials. The stoichiometric amounts of chemicals were mixed homogeneously and transferred to Pt crucibles to melt at a temperature of $1400{ }^{\circ} \mathrm{C}$ for $2 \mathrm{~h}$ in air. After melting, the melt was quickly quenched into deionized water and ground, followed by screened through a 500-mesh stainless steel wire screen to obtain glass powders with particle size less than $25 \mu \mathrm{m}$.

\subsection{Characterization of the samples}

The XRD patterns of crushed powder samples were recorded within angular range $10-80^{\circ}$ using PANalytical X'Pert PRO with $\mathrm{Cu} \mathrm{K} \alpha$ radiation $(\lambda=1.54 \AA)$. The $2 \theta$ angle scans were made at step width of $0.02^{\circ}$ and a time per step of $0.5 \mathrm{~s}$.

The density of all glasses was examined using AccuPyc®II 1340 (Micromeritics USA). The data was tested ten times to obtain an accurate density value. Fourier transform infrared spectra (FT-IR, Thermo Nicolet Smart-380) were carried out in the range $400-2000 \mathrm{~cm}^{-1}$ at room temperature with a resolution of $2 \mathrm{~cm}^{-1}$ on glass powders. Samples were mixed with spectroscopic grade dry $\mathrm{KBr}$ powder and then compressed the mixtures to obtain pellets for FT-IR measurements.

A Differential Scanning Calorimetry (DSC, STA409 PG/PC, Netzsch, Germany) was carried out to determine the glass transition temperature $\left(T_{\mathrm{g}}\right)$ and the crystallization behavior. The test was conducted in a flowing atmosphere of dry air from ambient temperature to $1000{ }^{\circ} \mathrm{C}$ with a heating rate of $\beta=5{ }^{\circ} \mathrm{C}$ $\min ^{-1}$. The DSC experiments were carried out using alumina crucibles with a- $\mathrm{Al}_{2} \mathrm{O}_{3}$ powder as a reference material.

${ }^{11} \mathrm{~B},{ }^{27} \mathrm{Al}$ and ${ }^{29} \mathrm{Si}$ magic angle spinning nuclear magnetic resonance spectroscopy (MAS-NMR, Varian Infinity-plus 400) were performed on all glasses to determine the roles of $\mathrm{B}, \mathrm{Si}$ and $\mathrm{Al}$ in glasses system. The definite test condition refers to ref. 13.

\section{Results and discussion}

\subsection{The XRD analysis}

Fig. 1 presented the X-ray diffraction conducted on the glasses, which showed the diffusion peaks and no crystalline phases, indicating the amorphous state of all glasses.

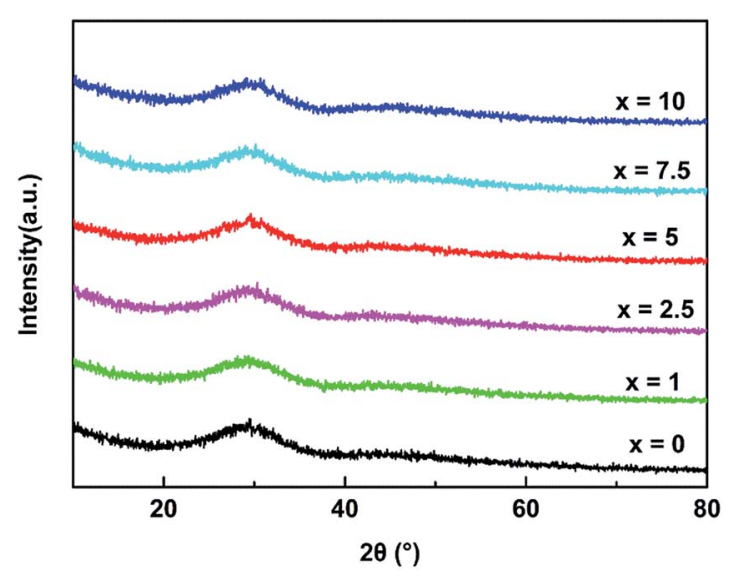

Fig. 1 X-ray diffraction patterns of glasses.
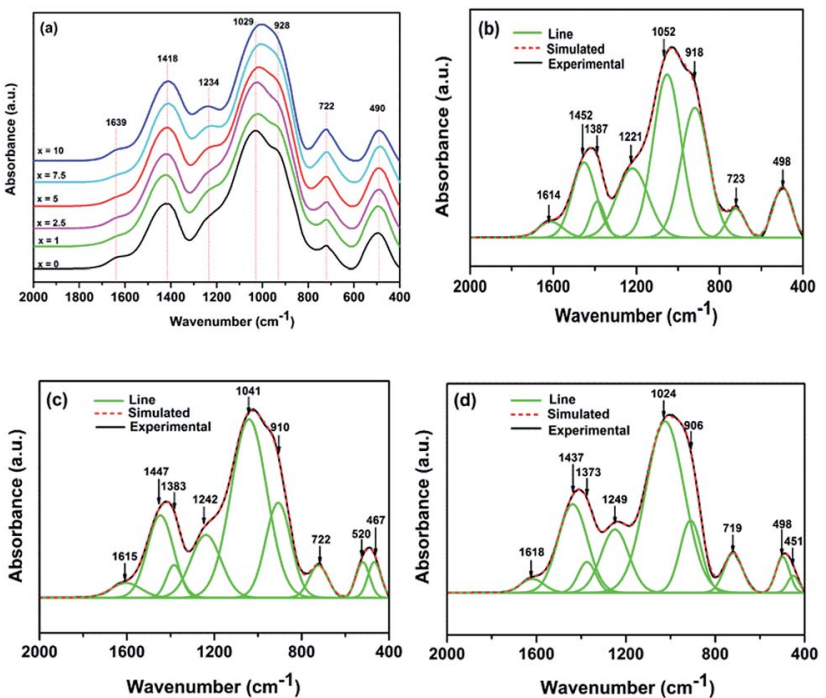

Fig. 2 (a) The FT-IR spectra of the glasses; deconvoluted FT-IR spectra of the glasses based on Gaussian function, (b) $x=0$, (c) $x=5$, (d) $x=10$.

\subsection{The FT-IR analysis}

The FT-IR spectra of all glasses for $x=0,1,2.5,5,7.5$ and 10 mol\% between 400 and $2000 \mathrm{~cm}^{-1}$ are shown in Fig. 2(a), respectively. The broad bands showed in FT-IR absorbance spectra confirm the amorphous nature (as showed in Fig. 1) and wide distribution of $\mathrm{Q}^{n}\left(\mathrm{Q}^{n}\right.$ notation indicates $n$ bridging oxygen per tetrahedron) units of glasses. All experimental glass compositions showed similar FT-IR spectra and the absorption bands are broad resulting in different component peaks to form overlap easily. Therefore, it is necessary to utilize the deconvolution based on Gaussian function to identify each component peak of all bands in the FT-IR spectra to realize their assignments. Fig. 2(b)-(d) represent the deconvoluted spectra of glasses for $x=0, x=5$ and $x=10 \mathrm{~mol} \%$ as examples of the glasses investigated, respectively. The high frequency band around $1620 \mathrm{~cm}^{-1}$ is attributed to the molecular water. ${ }^{14}$ The band near $1450 \mathrm{~cm}^{-1}$ and $1380 \mathrm{~cm}^{-1}$ are characteristic of antisymmetric stretching vibration of $\left[\mathrm{BO}_{3}\right] .{ }^{15}$ The band at 1234 $\mathrm{cm}^{-1}$ is due to the corresponding mode of borate triangles with non-bridging oxygen (NBO) atoms, which are mainly $\mathrm{BO}_{2} \mathrm{O}^{-}$ triangles with two bridging and one non-bridging oxygen atom. ${ }^{16}$ It is notable that the intensity of the band at $1234 \mathrm{~cm}^{-1}$
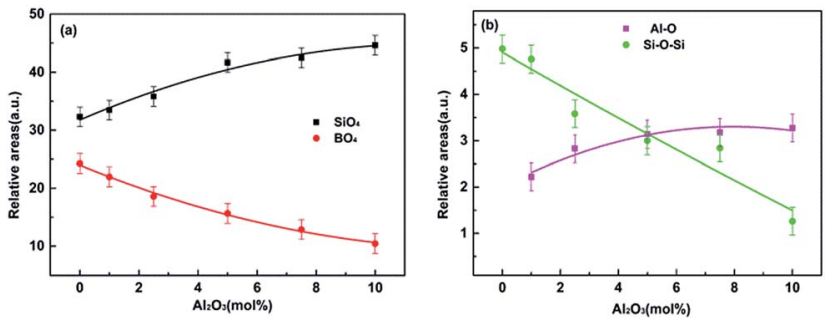

Fig. 3 Dependence of the relative area of $\mathrm{SiO}_{4}, \mathrm{BO}_{4}$ group (a) and $\mathrm{Al}-$ $\mathrm{O}, \mathrm{Si}-\mathrm{O}-\mathrm{Si}(\mathrm{b})$ on $\mathrm{Al}_{2} \mathrm{O}_{3}$ content. The lines are guide for the eyes. 
(a)
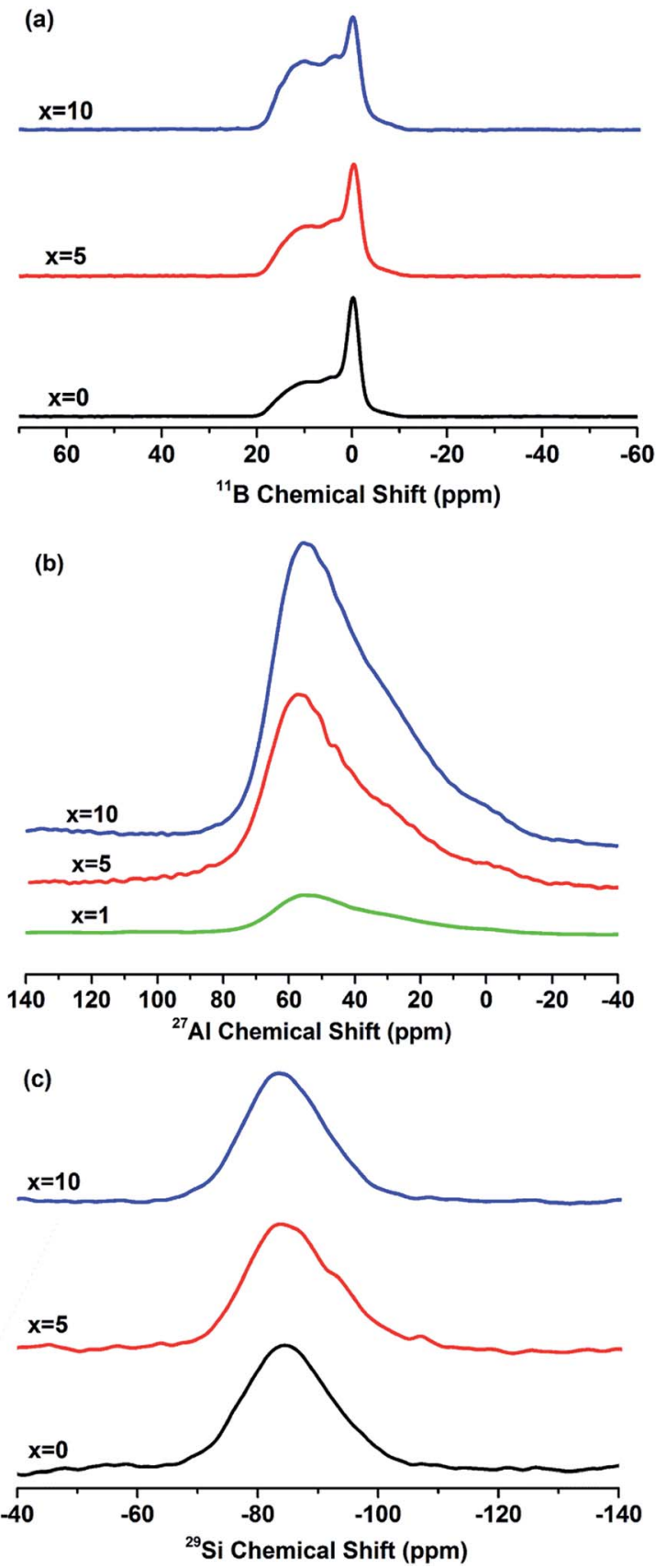

Fig. 4 NMR spectra of (a) ${ }^{11} \mathrm{~B}$, (b) ${ }^{27} \mathrm{Al}$ and (c) ${ }^{29} \mathrm{Si}$ of experimental glasses.

increases gradually with the $\mathrm{Al}_{2} \mathrm{O}_{3}$ content increasing, revealing the enhancement of borate triangles with NBOs proportion in glasses. The band located around $1030 \mathrm{~cm}^{-1}$ assigned to the merging bands of the $\mathrm{SiO}_{4}$ tetrahedral, ${ }^{4}$ and the band shifted to lower wavenumber, the wavenumber of this band location are separately $1052,1048,1043,1041,1036,1024 \mathrm{~cm}^{-1}$ from $x=0$ to $x=10$, respectively, indicating the addition of $\mathrm{Al}_{2} \mathrm{O}_{3}$ may change the combination mode in glasses. The band near 910 $\mathrm{cm}^{-1}$ is due to $\mathrm{B}-\mathrm{O}$ stretching in $\mathrm{BO}_{4}$ units ${ }^{17}$ and its intensity becomes weaker as the increasing $\mathrm{Al}_{2} \mathrm{O}_{3}$ content. Additionally, the relative areas of the peak corresponding to $\mathrm{SiO}_{4}$ and $\mathrm{BO}_{4}$
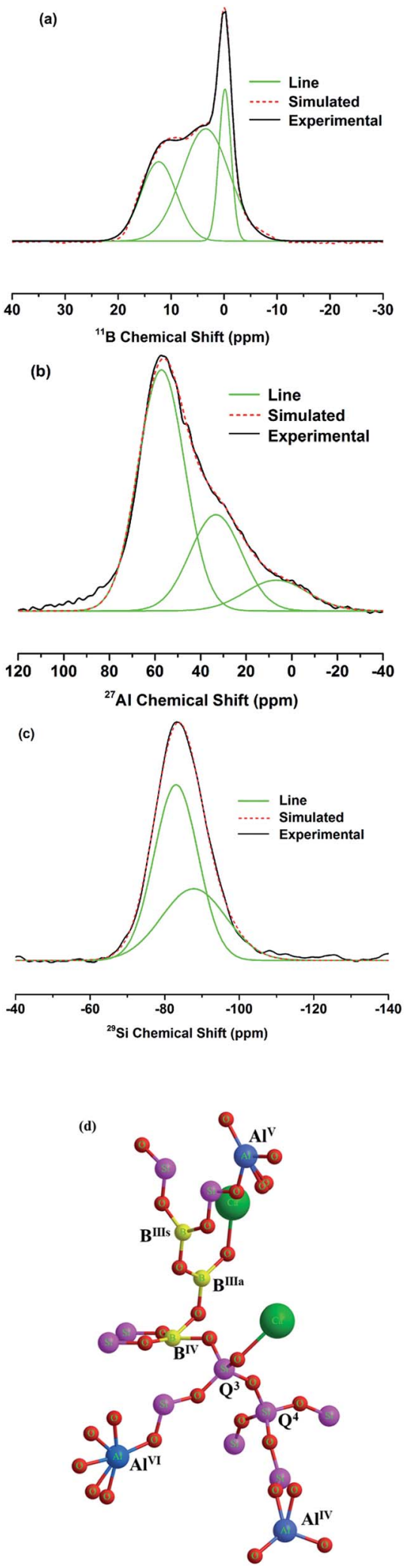

Fig. 5 Deconvolution of (a) ${ }^{11} \mathrm{~B}$, (b) ${ }^{27} \mathrm{Al}$ and (c) ${ }^{29} \mathrm{Si}$ NMR spectra for glass with $x=5$. (d) The ball-and-stick models for species in glasses.

units were calculated according to the assignment of the IR spectra, showed in Fig. 3(a). It reveals that the amount of $\mathrm{SiO}_{4}$ increase while the $\mathrm{BO}_{4}$ units reduce in glass system with the 
Table 1 NMR parameters for ${ }^{11} \mathrm{~B}$ deconvolution

\begin{tabular}{llrl}
\hline & Boron site & $\delta_{\text {iso }}(\mathrm{ppm})$ & Amount (\%) \\
\hline \multirow{2}{*}{$x=0$} & $\mathrm{~B}^{\mathrm{IIIa}}$ & 11.97 & 26.44 \\
& $\mathrm{~B}^{\mathrm{IIIs}}$ & 3.17 & 44.68 \\
& $\mathrm{~B}^{\mathrm{IV}}(1 \mathrm{~B}, 3 \mathrm{Si})$ & -0.28 & 28.88 \\
& $\mathrm{~B}^{\text {III }}$ & 12.33 & 28.14 \\
& $\mathrm{~B}^{\text {IIIs }}$ & 3.47 & 53.38 \\
& $\mathrm{~B}^{\text {IV }}(1 \mathrm{~B}, 3 \mathrm{Si})$ & -0.17 & 18.48 \\
& $\mathrm{~B}^{\text {IIIa }}$ & 12.47 & 32.70 \\
& $\mathrm{~B}^{\text {IIIs }}$ & 3.64 & 54.98 \\
& $\mathrm{~B}^{\text {IV }}(1 \mathrm{~B}, 3 \mathrm{Si})$ & -0.04 & 12.32
\end{tabular}

increasing $x$. The appeared band of $722 \mathrm{~cm}^{-1}$ is attributed to stretching vibrations of $\mathrm{Al}-\mathrm{O}$ bond in $\left[\mathrm{AlO}_{4}\right]$ tetrahedral ${ }^{18}$ and the bending vibration of the $\mathrm{B}-\mathrm{O}-\mathrm{B}$ bonds in the borate network; ${ }^{18,19}$ the band located around $500 \mathrm{~cm}^{-1}$ and $467 \mathrm{~cm}^{-1}$ are attributed to the $\mathrm{Al}-\mathrm{O}$ stretching vibrations in $\left[\mathrm{AlO}_{6}\right]$ octahedral and the bending vibration of $\mathrm{Si}-\mathrm{O}-\mathrm{Si}^{\mathbf{1 9 , 2 0}}$ Their relative areas are depicted in Fig. 3(b). The results show that the bending vibration of $\mathrm{Si}-\mathrm{O}-\mathrm{Si}$ weakens and the $\mathrm{Al}-\mathrm{O}$ stretching vibrations increase.

\subsection{MAS-NMR spectroscopy}

The ${ }^{11} \mathrm{~B}$ MAS-NMR spectra of the glasses with different $\mathrm{Al}_{2} \mathrm{O}_{3}$ content are shown in Fig. 4(a). The spectra show relatively broad peaks located at $11 \mathrm{ppm}$ and $4 \mathrm{ppm}$ are corresponding to asymmetric ( $\mathrm{B}^{\mathrm{III}}$, boron with 1 or 2 bridging oxygens) and symmetric trigonal ( $\mathrm{B}^{\mathrm{IIIs}}$, boron with 0 or 3 bridging oxygens) boron units, ${ }^{21}$ respectively. The units are showed in the Fig. 5(d), the ball-and-stick models for species in glasses. And another sharper peak centered $0 \mathrm{ppm}$ associated with tetrahedral $\left(\mathrm{BO}_{4}\right.$, $\mathrm{B}^{\mathrm{IV}}$ ) boron species, ${ }^{21}$ which is similar to borosilicate mineral superstructures danburite units $\left[\mathrm{B}(\mathrm{OB})(\mathrm{OSi})_{3}\right] \cdot{ }^{22}$ It is noteworthy that the intensity of $\left[\mathrm{BO}_{3}\right]$ units increases distinctly with the increasing of $x$, indicating the rising amount of $\left[\mathrm{BO}_{3}\right]$ units in glasses. In order to quantitatively figure out the distribution of $\mathrm{B}^{\mathrm{III}}$ and $\mathrm{B}^{\mathrm{IV}}$ units of boron in glasses, the ${ }^{11} \mathrm{~B}$ MAS-NMR spectra were deconvoluted and the example of $x=5$ was showed in Fig. 5(a), and their NMR parameters, the isotropic chemical shift $\left(\delta_{\text {iso }}\right)$ and the relative amount of structure units, were showed in Table 1 . The $\delta_{\text {iso }}$ of all boron units shifts to a higher value obviously with the increasing $x$, i.e. the value shifts from

Table 2 NMR parameters for ${ }^{27} \mathrm{Al}$ deconvolution

\begin{tabular}{llrl}
\hline & Aluminum site & $\delta_{\text {iso }}(\mathrm{ppm})$ & Amount $(\%)$ \\
\hline \multirow{2}{*}{$x=1$} & $\mathrm{Al}^{\mathrm{IV}}$ & 57.14 & 61.82 \\
& $\mathrm{Al}^{\mathrm{V}}$ & 33.27 & 27.31 \\
& $\mathrm{Al}^{\mathrm{VI}}$ & 6.74 & 10.85 \\
& $\mathrm{Al}^{\mathrm{IV}}$ & 57.16 & 61.92 \\
& $\mathrm{Al}^{\mathrm{V}}$ & 33.27 & 27.44 \\
& $\mathrm{Al}^{\mathrm{VI}}$ & 6.74 & 10.63 \\
& $\mathrm{Al}^{\mathrm{IV}}$ & 55.31 & 57.04 \\
& $\mathrm{Al}^{\mathrm{V}}$ & 32.67 & 32.87 \\
& $\mathrm{Al}^{\mathrm{VI}}$ & 6.74 & 10.08
\end{tabular}

11.97 to 12.47 for $\mathrm{B}^{\mathrm{III}}$, from 3.17 to 3.64 for $\mathrm{B}^{\mathrm{IIIs}}$ and from -0.28 to -0.04 for $\mathrm{B}^{\mathrm{IV}}$. In addition, the relative amount of $\mathrm{B}^{\mathrm{III}}$ units increases from $26.44 \%$ to $32.7 \%$ and $\mathrm{B}^{\mathrm{IIIs}}$ is from $44.68 \%$ to $54.98 \%$, while the $\mathrm{B}^{\mathrm{IV}}$ units decrease from $28.88 \%$ to $12.32 \%$ with the increasing of $\mathrm{Al}_{2} \mathrm{O}_{3}$ content (Table 1). The results are in accordance with previous outcome revealed by the band at 1234 $\mathrm{cm}^{-1}$ and $928 \mathrm{~cm}^{-1}$ in FT-IR.

Fig. 4(b) revealed the ${ }^{27} \mathrm{Al}$ MAS-NMR spectra of the glasses with $x=1,5$ and 10 . The spectra showed a narrow peak centered at $55 \mathrm{ppm}$ are associated with $\mathrm{Al}^{\mathrm{IV}}$ unit ${ }^{23}$ and the peak is sharper with the increasing of $x$, which shows the enhancement of $\mathrm{Al}$ units in glasses. In addition, the peaks are asymmetrical and broader demonstrating the presence of higher Al coordination, ${ }^{23}$ such as $\mathrm{Al}^{\mathrm{V}}$ and $\mathrm{Al}^{\mathrm{VI}}$ units. In order to quantitatively clarify the fractions and distribution of different Al coordination in glasses, the spectral deconvolution was performed using Gaussian by fitting one line shape and an example of $x=5$ was presented in Fig. 5(b), and the isotropic chemical shift $\left(\delta_{\text {iso }}\right)$ and the relative amount of different $\mathrm{Al}$ coordination units were showed in Table 2 . The peaks having chemical shifts around 55, 33 and $6.7 \mathrm{ppm}$ can be attributed to $\mathrm{Al}^{\mathrm{IV}}, \mathrm{Al}^{\mathrm{V}}$ and $\mathrm{Al}^{\mathrm{VI}}$ species (as showed in Fig. 5(d)), ${ }^{13}$ respectively. With the increasing of $x$, the relative amount of $\mathrm{Al}^{\mathrm{IV}}$ units decreases from $61.82 \%$ to $57.04 \%$ and the $\mathrm{Al}^{\mathrm{VI}}$ is from $10.85 \%$ to $10.08 \%$, while the $\mathrm{Al}^{\mathrm{V}}$ increases from $27.31 \%$ to $32.87 \%$.

The ${ }^{29}$ Si MAS-NMR spectra for $x=0,5$ and 10 were showed in Fig. 4(c). Deconvolution of ${ }^{29} \mathrm{Si}$ spectra was performed using Gaussian to quantitatively analyze the existence form and fractions of Si units. An example of ${ }^{29} \mathrm{Si}$ deconvolution of $x=5$ is presented in Fig. 5(c) and their NMR parameters are presented in Table 3. The results showed that two peaks around -84 and $-90 \mathrm{ppm}$ for all glasses, which are characteristic of the $\mathrm{Q}^{3}$ and $\mathrm{Q}^{4}$ structural units of silicon (as showed in Fig. 5(d)), respectively. The chemical shifts of $\mathrm{Q}^{4}$ structural units shift from -97.01 to $-87.79 \mathrm{ppm}$ and $\mathrm{Q}^{3}$ has no obvious change. Also, the relative amount of $\mathrm{Q}^{4}$ structural units increases clearly from $5.78 \%$ to $37.4 \%$, while the $\mathrm{Q}^{3}$ decreases from $94.21 \%$ to $62.59 \%$ for $x=0$ to $x=10$.

The previous structural studies (FT-IR, NMR) have shown that $\mathrm{B}$ occurs as $\mathrm{B}^{\mathrm{III} a}, \mathrm{~B}^{\mathrm{IIIs}}$ and $\mathrm{B}^{\mathrm{IV}}(1 \mathrm{~B}, 3 \mathrm{Si})$ species, $\mathrm{Al}$ occurs in 4 , 5 , and 6-fold coordination $\left(\mathrm{Al}^{\mathrm{IV}}, \mathrm{Al}^{\mathrm{V}}\right.$ and $\left.\mathrm{Al}^{\mathrm{VI}}\right)$ and Si presents in $\mathrm{Q}^{3}$ and $\mathrm{Q}^{4}$ units in the glasses. This shows the intermediate oxides $\mathrm{Al}_{2} \mathrm{O}_{3}$ may partly act as glass network former in glasses researched in this paper. The structural changes (Table 1) that the $\mathrm{B}^{\mathrm{IV}}$ species resolve into symmetric $\mathrm{BO}_{3}$ species and nonbridging oxygen can be shown as: ${ }^{13}$

Table 3 NMR parameters for ${ }^{29} \mathrm{Si}$ deconvolution

\begin{tabular}{llll}
\hline & Silicon units & $\delta_{\text {iso }}(\mathrm{ppm})$ & Amount $(\%)$ \\
\hline \multirow{2}{*}{$x=0$} & $\mathrm{Q}^{3}$ & -84.47 & 94.21 \\
& $\mathrm{Q}^{4}$ & -97.01 & 5.78 \\
\multirow{4}{*}{$x=5$} & $\mathrm{Q}^{3}$ & -83.67 & 72.36 \\
& $\mathrm{Q}^{4}$ & -94.03 & 27.63 \\
& $\mathrm{Q}^{3}$ & -83.06 & 62.59 \\
& $\mathrm{Q}^{4}$ & -87.79 & 37.4
\end{tabular}




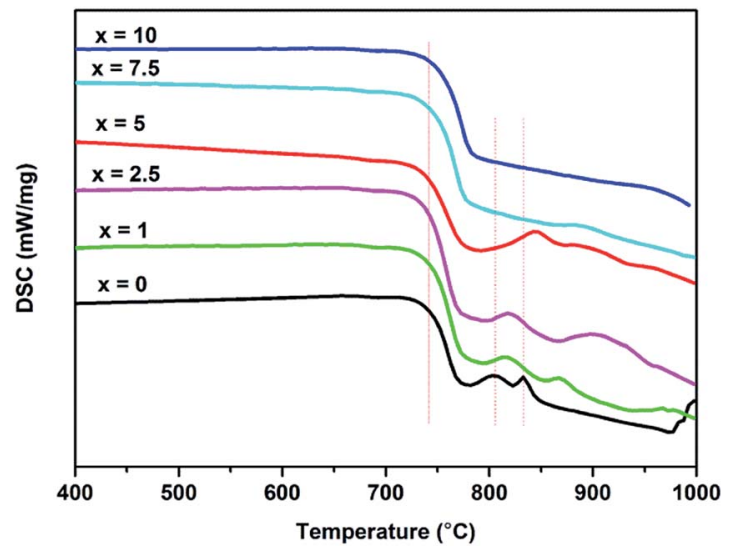

Fig. 6 DSC curve of the studied glasses.

$$
\mathrm{BO}_{4} \leftrightarrow \mathrm{B}^{\mathrm{IIIs}}+\mathrm{NBO}
$$

The variation occurred in $\mathrm{B}^{\mathrm{III}}$ and $\mathrm{B}^{\mathrm{IIIs}}$ species can be written as the following reaction: ${ }^{13}$

$$
\mathrm{B}^{\mathrm{IIIs}}+\mathrm{NBO} \leftrightarrow \mathrm{B}^{\mathrm{IIIa}}
$$

Moreover, the $\mathrm{SiO}_{4}$ units with $n$ bridging oxygen $\left(\mathrm{Q}^{n}\right)$ may combine with the non-bridging oxygen to form the $\mathrm{Q}^{n-1}$ unit. The change can be presented as: ${ }^{13}$

$$
\mathrm{Q}^{n}+\mathrm{NBO} \leftrightarrow \mathrm{Q}^{n-1}
$$

The shift of $\mathrm{Al}^{\mathrm{IV}}, \mathrm{Al}^{\mathrm{V}}$ and $\mathrm{Al}^{\mathrm{VI}}$ species with $\mathrm{NBO}$ can be represented as:

$$
\mathrm{Al}^{\mathrm{V}} \leftrightarrow \mathrm{Al}^{\mathrm{IV}}+\mathrm{NBO}
$$

As increasing of $\mathrm{Al}_{2} \mathrm{O}_{3}$ content, the relative amount of $\mathrm{Al}^{\mathrm{IV}}$ units decreases while the $\mathrm{Al}^{\mathrm{V}}$ increases, and the $\mathrm{Al}^{\mathrm{VI}}$ remains stable (Table 2). These results shows that the $\mathrm{Al}^{\mathrm{IV}}$ units can capture more $\mathrm{NBO}$ to form the $\mathrm{Al}^{\mathrm{V}}$ units, however, the $\mathrm{Al}^{\mathrm{IV}}$ units have not enough $\mathrm{NBO}$ to shape the $\mathrm{Al}^{\mathrm{VI}}$ units. The NBOs captured by $\mathrm{Al}^{\mathrm{IV}}$ units may be originated in the dissociation of $\mathrm{BO}_{4}$ species (eqn (1)), which was consistent with the result revealed in Table 1 . At the same time, due to the competition of $\mathrm{Al}$ units to gain the more NBOs, the relative amount of $\mathrm{Q}^{4}$ structural unit increases while the $\mathrm{Q}^{3}$ decreases (Table 3). This can account for the eqn (2). Therefore, the increasing concentration of $\mathrm{Al}$ substitution in glasses will lead to the decrease of
NBOs, which will make the amount of $\mathrm{BO}_{3}, \mathrm{Q}^{4}$ units increase while $\mathrm{BO}_{4}$ and $\mathrm{Q}^{3}$ units decrease.

\subsection{Thermal, phase and physical properties of glasses}

Fig. 6 presents the DSC plots of all the glasses measured at $\beta=$ $5{ }^{\circ} \mathrm{C} \mathrm{min}{ }^{-1}$. The curves show 2 crystallization peaks $\left(T_{\mathrm{P} 1}\right.$ and $T_{\mathrm{P} 2}$ ), related to the formation of the crystalline phase of wollastonite $^{24}$ and borocalcite, ${ }^{25}$ respectively. With the increasing of $\mathrm{Al}_{2} \mathrm{O}_{3}$ content, the $T_{\mathrm{P} 1}$ and $T_{\mathrm{P} 2}$ shift in the direction of the higher temperature and gradually disappear. Table 4 presents the values of $T_{\mathrm{g}}$ (glass transition temperature), $T_{\mathrm{P} 1}$ and $T_{\mathrm{P} 2}$. The $T_{\mathrm{g}}$ is obtained from the onset of slope change of the DSC curves. The values of $T_{\mathrm{g}}$ for all glasses don't appear to be much different considering the error factor. The first crystallization peak $T_{\mathrm{P} 1}$ successively increases with $\mathrm{Al}_{2} \mathrm{O}_{3}$ content from 805 to $945{ }^{\circ} \mathrm{C}$, however, the second crystallization peak $T_{\mathrm{P} 2}$ increases obviously with increasing $x$ up to $x=5 \mathrm{~mol} \%$, and then disappears with the further increasing $x$ in the whole measuring temperatures.

Fig. 7(a) shows the XRD patterns of all glasses isothermally treated once for $1 \mathrm{~h}$ at temperature of $850^{\circ} \mathrm{C}$ with $x=0,2.5,7.5$ and 10. It could be observed that the peak of crystallization become weaker gradually with the increasing of $x$, and the glass with $x=10$ remains the glassy state. The main diffraction peaks for $x=0,2.5$ and 7.5 can be indexed to the $\mathrm{CaSiO}_{3}$ (JCPDS No. 10-0487), and a few diffraction peaks corresponding to $\mathrm{CaB}_{2} \mathrm{O}_{4}$ (JCPDS No. 01-0833) phase. This result conforms to the change of crystallization peaks $\left(T_{\mathrm{P} 1}\right.$ and $\left.T_{\mathrm{P} 2}\right)$ in DSC analysis as shown in Fig. 6. The Fig. 7(b)-(d) show the XRD patterns of glasses with $x=0,5$ and 10 , respectively. All samples were isothermally treated four times for $1 \mathrm{~h}$ at temperature of $850{ }^{\circ} \mathrm{C}$. Fig. 7(b) revealed that the patterns of sample with $x=0$ implemented repeated heat treatment were about the same. This result illustrates the sample was crystallized completely when heated at the first time. For sample with $x=5$, the repeated heat treatment makes the crystallization more complete. However, for sample with $x=10$, the crystallization was emerged until the third time heat treatment. This observation confirms previous findings, that chemically weak inclusions do not provide active foreign nucleation substrates. ${ }^{26}$ One of the most remarkable things about these patterns is that the crystalline phases, not just the $\mathrm{CaSiO}_{3}$ and $\mathrm{CaB}_{2} \mathrm{O}_{4}$ phase, the most is the $\mathrm{Ca}_{2} \mathrm{SiO}_{4}$ (JCPDS No. 49-1672). These results revealed that the addition of

\begin{tabular}{|c|c|c|c|c|c|c|}
\hline$x=0$ & 745 & 805 & 833 & $2.845 \pm 0.004$ & 26.8 & 3.18 \\
\hline$x=2.5$ & 746 & 818 & 902 & $2.824 \pm 0.003$ & 27.3 & - \\
\hline$x=5$ & 744 & 845 & 955 & $2.810 \pm 0.003$ & 27.6 & 2.87 \\
\hline$x=7.5$ & 747 & 884 & - & $2.801 \pm 0.004$ & 27.9 & - \\
\hline
\end{tabular}
$\mathrm{Al}_{2} \mathrm{O}_{3}$ in glasses may hinder the crystallization of CBS glasses. This can be ascribed to the addition of $\mathrm{Al}_{2} \mathrm{O}_{3}$ dopants, dissolved

Table 4 Characteristic temperatures and physical properties for all glasses 

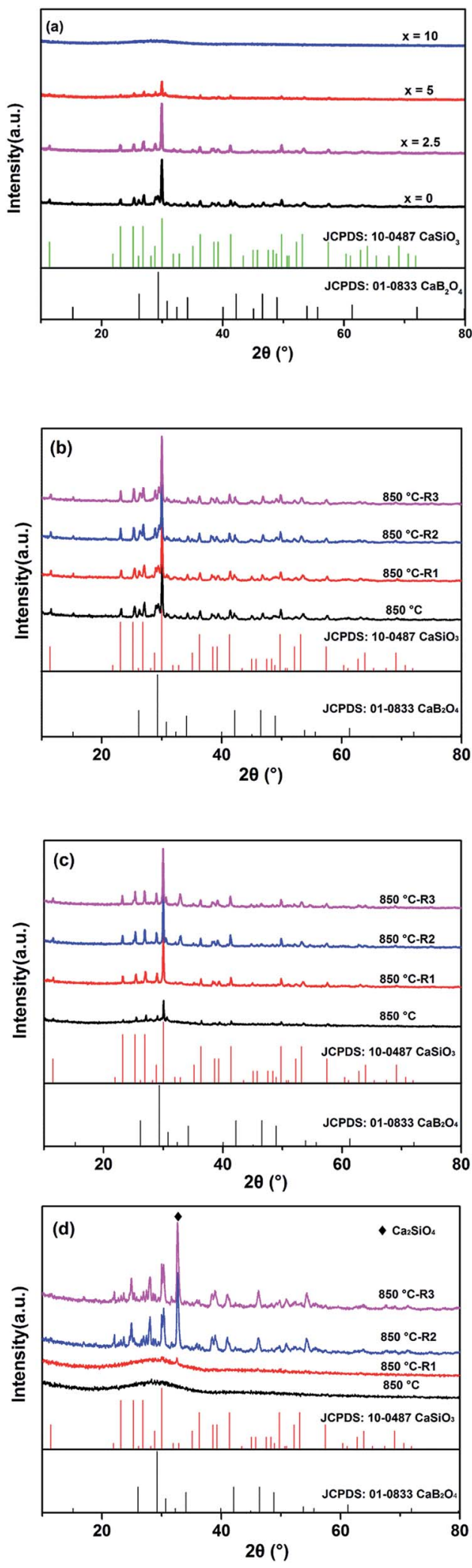

Fig. $7 \quad X$-ray diffraction patterns of crystallized glasses at temperature of $850^{\circ} \mathrm{C}$. (a) The patterns glasses isothermally treated one time for $x=$ $0,2.5,5$ and 10 . The patterns of glasses isothermally treated four times (b) $x=0$; (c) $x=5$; (d) $x=10$. in glass system, modifies the thermodynamic equilibrium of the system and this change is mainly entropy driven and also slowdown the kinetics of crystallization. ${ }^{27}$ The addition of $\mathrm{Al}_{2} \mathrm{O}_{3}$ leads to the reconnection of fractured silicon oxygen tetrahedron and a large extent of atomic rearrangements. This will make the glass need higher thermal energies to crystallize, resulting the increasing of crystallization temperature (Fig. 6 and Table 4).

The density and the molar volume $\left(V_{\mathrm{m}}\right)$ of all glasses for $x=$ $0,1,2.5,5,7.5$ and 10 also showed in Table 4 . The molar volume $\left(V_{\mathrm{m}}\right)$ could be calculated using the following formula: ${ }^{28}$

$$
V_{\mathrm{m}}=\frac{M}{\rho}
$$

where $M$ and $\rho$ are molecular weight and density of the glass, respectively. As shown in Table 4, the density $(\rho)$ of glasses decreased linearly form 2.845 to $2.786 \mathrm{~g} \mathrm{~cm}^{-3}$ with increasing $\mathrm{Al}_{2} \mathrm{O}_{3}$ content, while the molar volume $\left(V_{\mathrm{m}}\right)$ of the glasses increases linearly. The physical properties of borosilicate glasses depend on the structural units in glasses, which are closely bound up with $\mathrm{BO}_{3}, \mathrm{BO}_{4}, \mathrm{Q}^{n}$ units and $\mathrm{Al}$ species. Based on the deconvolution results in FT-IR, the relative areas of the peak corresponding to $722 \mathrm{~cm}^{-1}$ in sample with $x=0$ were $3.53 \%$, while the relative areas of the peaks corresponding to $722 \mathrm{~cm}^{-1}$ and $500 \mathrm{~cm}^{-1}$ in sample with $x=10$ were $4.94 \%$ and $3.27 \%$, respectively. Therefore, the relative areas of Al-O in sample with $x=10$ were approximately $4.5 \%$, and the relative areas of B-O and Si-O were $48 \%$ and $46 \%$, respectively. So, the $\mathrm{Al}$ species make up only a small percentage in glass system. In addition, the Al species changed a little (showed in Table 2), both of which cause a small contribution to the change of density. The change $\left(Q^{4}\right.$ units increase $Q^{3}$ units decrease) occurred in $\mathrm{Q}^{n}$ units will make the density increase. The impacts of B units on the density of glasses can be calculated according to eqn (6):

$$
\rho=\frac{w_{1} \%+w_{2} \%+w_{3} \%}{w_{1} \% / \rho_{1}+w_{2} \% / \rho_{2}+w_{3} \% / \rho_{3}}
$$

where $w$ and $\rho$ are the percentage and density of $\mathrm{B}^{\mathrm{IIIa}}, \mathrm{B}^{\mathrm{IIIS}}$ and $\mathrm{B}^{\mathrm{IV}}$ units, respectively. The value of $w_{1}, w_{2}$ and $w_{3}$ was showed in Table 1 . The density of the symmetric $\mathrm{BO}_{3}$ unit is $\sim 1.87 \mathrm{~g} \mathrm{~cm}^{-3}$, for the $\mathrm{BO}_{4}$ tetrahedron $\sim 6.77 \mathrm{~g} \mathrm{~cm}^{-3}$ and for the asymmetric $\mathrm{BO}_{3}$ unit $\sim 8.10 \mathrm{~g} \mathrm{~cm}^{-3} .^{29}$ The densities of B units for samples with $x=0,5$ and 10 were calculated and was listed in Table 4 based on the eqn (6). It can be seen that the $\rho_{\mathrm{B}}$ units decreases with the increasing of $x$ value, and its influence outweighs the $\mathrm{Q}^{n}$ units. These factors make the density of glasses decrease with the increasing $\mathrm{Al}_{2} \mathrm{O}_{3}$ content.

\section{Conclusions}

The current study using NMR, FT-IR, DSC and XRD investigated the role of $\mathrm{Al}$ on structure and crystallization of CBS glass when added at a small concentration. The Al partly plays the network former role in CBS glasses and the Al goes into the glass network in 4-fold, 5-fold and 6-fold coordination whereas B goes in as both 4 - and 3-fold coordination. The Si occurred in the form $\mathrm{Q}^{3}$ 
and $\mathrm{Q}^{4}$ units. With the increasing of $\mathrm{Al}_{2} \mathrm{O}_{3}$ content, the amount of $\mathrm{BO}_{3}, \mathrm{Q}^{4}$ units increase while $\mathrm{BO}_{4}, \mathrm{Q}^{3}$ units decrease. This is due to the NBOs competition occurred in $\mathrm{Al}, \mathrm{B}$ and $\mathrm{Si}$ units. The density $(\rho)$ of glasses decreased linearly with increasing $\mathrm{Al}_{2} \mathrm{O}_{3}$ content, while the molar volume $\left(V_{\mathrm{m}}\right)$ of the glasses increases linearly. The glass transition temperatures for all glasses don't appear to be much different, while the crystallization peaks of glasses containing Al shift to higher temperatures and disappear. At the same time, the peaks of crystallization become weaker gradually with the increasing of $x$. These results indicate that $\mathrm{Al}$ can hinder the crystallization of CBS glasses.

\section{Acknowledgements}

The authors thank the National Center for Magnetic Resonance in Wuhan acquiring the MAS-NMR measurement. This work was supported by the fund of the Basic Applied Research Foundation of Yunnan Province, China (Grant No. 2016FD125, 2016FB083), the 551 project of Kunming and Science \&Technology Program of Yunnan Province (No. 2014DC019).

\section{References}

1 G. Shao, X. Wu, Y. Kong, X. Shen, S. Cui, X. Guan, C. Jiao and J. Jiao, J. Alloys Compd., 2016, 663, 360-370.

2 M. Y. Hassaan, H. M. Osman, H. H. Hassan, A. S. El-Deeb and M. A. Helal, Ceram. Int., 2017, 43, 1795-1801.

3 M. Klinger-Strobel, O. Makarewicz, M. W. Pletz, A. Stallmach and C. Lautenschlager, J. Mater. Sci.: Mater. Med., 2016, 27, 175.

4 M. Sitarz, J. Non-Cryst. Solids, 2011, 357, 1603-1608.

5 M. Ma, Z. Liu, F. Zhang, F. Liu, Y. Li and R. Bordia, J. Am. Ceram. Soc., 2016, 99, 2402-2407.

6 S. Cetinkaya Colak, I. Akyuz and F. Atay, J. Non-Cryst. Solids, 2016, 432, 406-412.

7 S. Khan, G. Kaur and K. Singh, Ceram. Int., 2017, 43, 722-727. 8 J.-Z. Liu, X.-F. Wu, N.-X. Xu, Q.-L. Zhang and H. Yang, J. Mater. Sci.: Mater. Electron., 2015, 26, 8899-8903.

9 D. R. Neuville, L. Cormier and D. Massiot, Chem. Geol., 2006, 229, 173-185.
10 S. Stefanovsky, K. Fox and J. Marra, MRS Proceedings, 2013, 1518, 53-58.

11 A. K. Yadav and P. Singh, RSC Adv., 2015, 5, 67583-67609.

12 A. Saini, A. Khanna, V. K. Michaelis, S. Kroeker, F. González and D. Hernández, J. Non-Cryst. Solids, 2009, 355, 2323-2332.

13 S. Sen, Z. Xu and J. Stebbins, J. Non-Cryst. Solids, 1998, 226, 29-40.

14 K. Singh, I. Bala and V. Kumar, Ceram. Int., 2009, 35, 34013406.

15 J. Wan, J. Cheng and P. Lu, J. Wuhan Univ. Technol., Mater. Sci. Ed., 2008, 23, 419-421.

16 A. Winterstein-Beckmann, D. Möncke, D. Palles, E. I. Kamitsos and L. Wondraczek, J. Non-Cryst. Solids, 2014, 405, 196-206.

17 K. Rao, Structural chemistry of glasses, Elsevier, 2002.

18 N. Santha, T. Nideep and S. Rejisha, J. Mater. Sci.: Mater. Electron., 2012, 23, 1435-1441.

19 G. J. Mohini, N. Krishnamacharyulu, G. Sahaya Baskaran, P. V. Rao and N. Veeraiah, Appl. Surf. Sci., 2013, 287, 46-53.

20 H. Shao, H. Q. Zhou and X. D. Shen, Adv. Mater. Res., 2011, 189-193, 4466-4471.

21 A. Gaddam, H. R. Fernandes and J. M. F. Ferreira, RSC Adv., 2015, 5, 41066-41078.

22 B. G. Parkinson, D. Holland, M. E. Smith, A. P. Howes and C. R. Scales, J. Phys.: Condens. Matter, 2007, 19, 415114.

23 S. H. Risbud, R. J. Kirkpatrick, A. P. Taglialavore and B. Montez, J. Am. Ceram. Soc., 1987, 70, C-10-C-12.

24 J. H. Jean, C. R. Chang and C. D. Lei, J. Am. Ceram. Soc., 2004, 87, 1244-1249.

25 C. R. Chang and J. H. Jean, J. Am. Ceram. Soc., 1999, 82, 17251732.

26 R. Müller, R. Meszaros, B. Peplinski, S. Reinsch, M. Eberstein, W. A. Schiller and J. Deubener, J. Am. Ceram. Soc., 2009, 92, 1703-1708.

27 A. Gaddam, H. R. Fernandes, M. J. Pascual, J. M. F. Ferreira and L. Pinckney, J. Am. Ceram. Soc., 2016, 99, 833-840.

28 A. Gaddam, H. R. Fernandes and J. M. Ferreira, RSC Adv., 2015, 5, 41066-41078.

29 H. Doweidar, K. El-Igili and S. A. El-Maksoud, J. Phys. D: Appl. Phys., 2000, 33, 2532. 